\title{
Four Models of Anarchist Engagements with Constitutionalism
}

\author{
Benjamin Franks*
}

Political anarchism's hostility to constitutional activity has been frequently identified as the core feature distinguishing it from other members of the socialist tradition. However, four minority anarchist traditions which engage in democratic activism can also be identified: minor formal engagement, horizontal structural reformism, revolutionary (anti-)representation, and guerrilla activism. To analyze these models of engagement, this paper examines their application to recent events such as the 2014 Scottish independence referendum and the 2016 Brexit referendum. The paper also draws out differences between the anti-politics of anarchism and those utilised by populist political movements in Europe and North America, and highlights how different strategies respond to and incorporate standard anarchist critiques of electoralism and state-centred democratic practice. It is argued that participation in referendums (direct democracy) is no less problematic than representative elections, but that some selective engagement can be justified on anarchist grounds. [Article copies available for a fee from The Transformative Studies Institute. E-mail address: journal@transformativestudies.org Website: http://www.transformativestudies.org (C2020 by The Transformative Studies Institute. All rights reserved.]

KEYWORDS: Anarchism, Constitutionalism, Electoralism, Prefiguration, Referendum.

\section{INTRODUCTION}

By looking at a group of socially-engaged, but electorally-sceptical political actors, I hope to highlight some criticisms of electoral strategies

\footnotetext{
* Benjamin Franks, Ph.D., is Senior Lecturer in Social and Political Philosophy at the University of Glasgow's Dumfries campus. He is the author of Rebel Alliances: The means and ends of contemporary British anarchisms (AK Press) and Anarchisms, PostAnarchisms and Ethics (Rowman and Littlefield), co-author, with Sean Johnston and Stuart Hanscomb of Environmental Ethics and Behavioural Change (Routledge) and coeditor with Nathan Jun and Leonard Williams of Anarchisms: A conceptual approach (Routledge). Address correspondence to: Benjamin Franks; email: Benjamin.Franks@glasgow.ac.uk.
} 